\title{
The Minaret of Kudus: Social Text and Harmony Narrative in Rural Java
}

\author{
R. Suharso ${ }^{1 *}$ Ganda Febri Kurniawan ${ }^{2}$ \\ ${ }^{1,2}$ Universitas Negeri Semarang \\ "Corresponding author. Email: harsohapsoro@mail.unnes.ac.id
}

\begin{abstract}
Objective of the study is to reveal the condition of Kudus Minaret as a social text and narrative of harmony between Javanese culture, Hinduism, and Islamism in rural Java. The study was conducted using a qualitative framework with a phenomenological design. The data source came from community leaders, cultural figures, and historical activists. Analysis of the data uses the Spradley model, namely the analysis of cultural content. The results study namely: a) people in rural Java still consider that the building is a symbol of tolerance in the community; and b) the historical knowledge and unity in diversity (In Java: bhinneka tunggal ika) is a driving factor in the formation of a community mindset about tolerance and social harmony. The conclusion is that although it is old, the building is still relevant as a glue for the people in rural Java who have diversity in terms of ethnicity, culture, and religion.
\end{abstract}

Keywords: Minaret of Kudus, Social Text, Harmony.

\section{INTRODUCTION}

The Minaret of Kudus is a building that has an important meaning in society. This building is still respected and valued as a historical legacy that binds people in an identity [1]. On the other hand, the problem of identity in various places becomes a problem that leads to the process of disintegration and conflict [2], [3]. Identity politics in the context of political contestation makes people face each other and increase sentiment among citizens, this is the most actual problem for Indonesian [4], therefore, a wellestablished social text is needed to make people aware of identity in a more dynamic context and not based on sentiment or hatred. In this case, the Kudus community has a unique historicity and is difficult to find in other regions. Historical record of the formation of society, with the building as its main symbol is the best architecture of all time that forms a social text about harmony and religious tolerance as well as culture [5]-[7].

According to Salam [8], that this building is the only one in Indonesia or in Southeast Asia that was built in the nuances of religious harmony, and that this is a masterpiece of Islamic civilization in Indonesia which from the beginning upheld the respect for predecessor religions, such as Hinduism and Buddhism. In addition, Islam in Java is a product of civilization not the result of coercion by political means [9]-[11]. So, understanding of this building, until now, still has an important meaning in an effort to build a harmonious society and can work together in various fields of life. In preliminary observations, around the building, people still highly respect as a product of the historical struggle to realize a dignified Islamic civilization in Java, this narrative can answer the doubts of scholars who assess the process of Islamization in Java running with violence and terror. Social texts about buildings can be a counter discourse that compares history that breeds discrimination and hatred between religions and cultures.

The present research departs from the Hosen hypothesis [12] which mentions that Islamization in Java is carried out in peaceful ways, in this case the cultural penetration and ongoing cultural processes emphasize a careful social process, so Islam can be quickly learned and understood by the community as a religion full of peace and reject all forms of oppression and violence. Another study that explains the Minaret of Kudus is Pradisa [5] Syafwandi [13] Salam [6] research from the scholars is still focused on the cultural meaning of the building, not highlighting the actual condition of the social construction of society. Salam [6] explained that this building was a symbol of the successful Islamization of Java peacefully, this condition for some people, especially 
those who are experiencing hatred or sentiments towards other religions, is very important, the dissemination of social texts about tolerance and social harmonization, according to Azra [10] needs to be done in an effort to develop a better social life and avoid conflict communities. This effort is the strength of the results of this study, a social text and a harmonious narrative symbolized by the Kudus tower in the current era is a valuable asset for the community in creating a peaceful atmosphere.

Based on the discussion above, this study aims to analyze social texts and the harmony of Javanese society symbolized by Minaret of Kudus. This research also looks at historical factors and single diversity as the basis for the formation of more progressive knowledge about peace by investigating people's understanding of the building. And also, this research makes an important contribution to development of social science about the epistemological meaning of buildings that can be disseminated as constructive reading material in the development efforts of people who have an awareness of peace.

\section{RESEARCH METHOD}

The present study was conducted qualitative methods with a phenomenological design [14]. The phenomenon is the Minaret of Kudus which is still believed by the community as a historic building that contains tolerance values. The data source of this research came from community leaders, cultural figures and historical activists. At least, this research has involved $15^{\text {th }}$ (fifteen) informants who are willing to provide data. All data was collected by in-depth interview techniques, direct observations were made to enrich information, viewpoints and complete the analysis process [15]. Data are examined using source triangulation techniques, each data that has been collected is checked for truth by comparing information provided by the informant. Check and Recheck becomes an important technique in the inspection process [16], [17]. Analysis of study used the Spradley model [18], namely analysis of cultural content. The data analysis technique consists of 4 (four) stages, namely; domain analysis, taxonomic analysis, component analysis, and the discovery of cultural themes. From Spradley model in general, domain analysis is used to obtain a general picture of social situations in the form of categories called domains. Then by the chosen domain taxonomy analysis is described in more detail. Furthermore, in compounding analysis, researchers look for specific characteristics in each internal structure by contrasting between elements. And the last is the discovery of cultural themes that are looking for relationships between domains and how the relationship between the whole is related to research themes.

\section{RESULT AND DISCUSSION}

The Minaret of Kudus which is currently attached to the Al Aqsa Mosque or Al Manar Mosque was built by Sunan Kudus or Ja'far Shodiq around 1549 AD. Located in Kauman Village, Kota District, Kudus Regency, Central of Java, Indonesia, this tower has a unique and distinctive shape. At first glance, the buildings is not like any other tower because it has a building similar to a temple [6], [19]. The architectural style of the temples in this building resembles temples in East Java, one of them is like the Jago Temple in Malang. In addition, this mosque building also resembles the Kukul Tower in Bali [20], [21]. The minaret which has a height of 17 meters and an area of about 100 square meters has become a symbol of acculturation between Hindu, Javanese, and Islamic culture. This building is archaeologically and historically high in value. This building became the symbol of the most monumental transition from Hindu Civilization to Islamic Civilization on Java. According to a developing story, Sunan Kudus built this tower by rubbing bricks with one another so that it would bond with one another and form a single building [22]. At the end of the minaret, which is roofed with two layers of teak wood construction, is supported by four teachers. In addition, there are also mustaka (dome) similar to overlapping roofs in traditional Javanese mosques [23], [24]. The function of the building when it was built until now is to make the call to prayer. The building is now a pilgrimage tourist attraction visited by many tourists who come from the territory of Indonesia, especially on certain days such as every $10^{\text {th }}$ of Muharram.

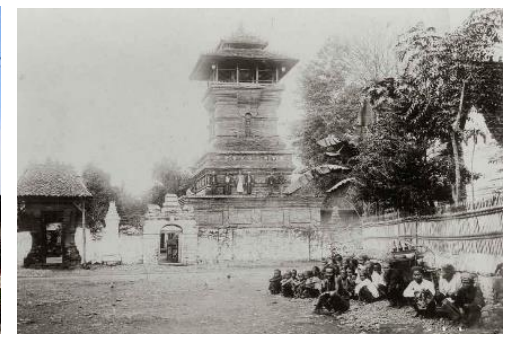

Figure 1. Minaret of Kudus, First = Right and Now = Left (Source: KITLV and Personal Documentation) 
The celebration of the anniversary of the Minaret of Kudus in 2020 was marked by the release of 485 pigeons into the air as a symbol of peace between religious communities in the country. The informant explained: "The number of pigeons was released so that the world could see the wisdom of universal wisdom and peace." The informant also explained:

\begin{abstract}
"the theme of wisdom and peace was chosen because at this time conflicts in the name of ethnicity and religion still often emerge, even later the sentiment of identity has strengthened again, after politics has been used for the benefit of power, not for the common interest and nationalism of Indonesia. While, since 485 years ago people already are required to reconcile ethnic and religious coexistence. This is actually a valuable lesson that should be read by every citizen."
\end{abstract}

The people still really understand that the Kudus Tower is a symbol of harmony left by Sunan Kudus, as a person who is highly valued in Kudus, all the relics of the figure are still preserved intact, one of which is the tradition and wisdom in Kudus. The Kudus community had the belief that the Menara was a form of wisdom from Sunan Kudus, who was Commander of the Demak Kingdom Military Force (1475-1554), not wanting bloodshed among Javanese people, the majority of whom at that time were still Hindus. This wisdom is reflected because Sunan Kudus had the opportunity to destroy Hindu civilization in his way, after the Islamic Kingdom of Demak defeated the Majapahit Kingdom (1293-1517) of Hindu-Buddhist [25], [26]. This became a very important event for the earthing of Islam afterward, a society that still adheres to the patron-client system sees Islam as a peaceful and more modern religion because it respects the human side, besides that in Islam there is no caste or static social strata. This has its own advantages for Islam, because it allows people to do vertical social mobility dynamically.

At the mosque's water level inside the mosque, there is a stone that reads Arabic. The stone has a length of $46 \mathrm{~cm}$ and a width of $30 \mathrm{~cm}$. The stone shield comes from Baitul Maqdis (Al-Quds) in Jerusalem, Palestine [19]. From the word Al-Quds, the name Kudus means holy. The mosque has five doors on the right, and five doors on the left. There are four windows in all. The big door consists of five pieces, and there are eight big pillars inside the mosque which are made of teak wood. Inside the mosque there is a mosque pool, a pool called the padasan is an ancient relic and used as a place of ablution. Informants argue:

"The Minaret of Kudus is a symbol of harmony, the community still respects this important relic of Sunan Kudus, we consider that this building is a sign of the founding of the city, as well as a form of peace inherited by Sunan Kudus in the past, this is very contextual with the present situation, where society still makes a good religion or ethnic identity to hate and that has the potential for disintegration."

The above opinion confirms that Javanese people still highly respect the history and all kinds of relics from Sunan Kudus. This historical reason is one of the factors that bind the Kudus community, in this city, until now the people still highly respect Hindu culture and traditions [5], [27], for example, for Muslim communities in the Kudus area, slaughtering cows is a taboo, this is a form of respect for Hindu society. For Hinduism, the Cow is a sacred animal, as is done by the people of India, while in Kudus to respect it all, the Muslim community does not slaughter Cows, but replaces them with Buffalo. This is a very important form of tolerance, which merges with the history of the Minaret of Kudus. Informants argue:

"Indonesia is a Bhinneka Tunggal Ika (In English: unity in diversity), yes, it has become a respected national philosophy, in the context of Islamic history, Sunan Kudus has shown a wise character, and in fact has carried out in practice a unity in diversity, long before Indonesia's independence in 1945. This is a responsibility history as well as culture to maintain and maintain harmony and tolerance in society, if we participate in identity conflicts, then we have violated historical provisions."

Bhinneka tunggal ika is meaningful despite being diverse but in essence the Indonesian people are still one entity [28]. This motto is used to describe the unity and unity of the Nation and the Unitary State of the Republic of Indonesia which consists of diverse cultures, regional languages, races, ethnicities, religions and beliefs. [29]. This has become an important rationale for the formation of a peaceful Indonesian society, the issue of ethnic, ethnic, religious and cultural differences has been resolved by this philosophy, so that it can be said that if conflicts still occur then the community has forgotten the history and philosophy of the Indonesian people. The people have a strong understanding of the philosophical and historical values of Indonesian civilization, so that they can maintain all forms of cultural heritage. Society shows wisdom, especially in maintaining relationships between people and preventing conflicts by relying on the value of wisdom and historical narratives which then make a harmonious and tolerant community. The results of this study confirm that the narratives of hatred and 
religious sentiments that are currently heating up are a form of ignorance of the history and philosophy of the nation that has been sparked since Indonesia's independence. This research supports the opinion of Hosen [12] Azra [10] Yusof [22] that Islam in Indonesia is spread by peaceful means, not war or other bloody conflicts. This civilizing process made Islam acceptable to the majority of Indonesian people as a religion full of peace.

\section{CONCLUSION}

The existence of the Minaret of Kudus still has an impact on society, the values left in the building are still believed by most people as the wisdom of the heritage of Sunan Kudus in the process of transition from Hindu Civilization to Islamic Civilization. The building is a symbol of peace, this is the result of the excavation of social text in the community, the harmony narrative about the building has now become an important oral tradition maintained by the community. The texts inherent in the building to date are historic buildings, city symbols, symbols of harmony, sacred buildings, full of positive memories, and become a binder for Javanese people who have a diversity of cultures, ethnicities, and religions. Although it has now been converted into a place of religious tourism, especially Islam, this building is still maintained its originality in terms of form. Caring for this building, for the community is caring for memories as well as values that have been firmly planted in the social life of the community to date.

\section{REFERENCES}

[1] A. M. Erzad and S. Suciati, "The Existence Of Kudus Islamic Local Culture to Prevent Radicalism in Globalization Era," QIJIS (Qudus International Journal of Islamic Studies), vol. 6, no. 1, pp. 39-56, 2018.

[2] A. R. Arifianto, "Islamic Campus Preaching Organizations in Indonesia: Promoters of Moderation or Radicalism?," Asian Security, pp. 1-20, 2018.

[3] W. R. Jati, "Radicalism in the perspective of Islamic-populism: trajectory of political Islam in Indonesia," Journal of Indonesian Islam, vol. 7, no. 2, pp. 268-287, 2013.

[4] R. Suharso, D. L. Setyowati, and C. B. Utomo, "Teaching Multiculturalism based on Islamic Historical Relics in Northern Java," International Journal of Innovation, vol. 11, no. 10, p. 19, 2020.

[5] A. P. Pradisa, "Perpaduan Budaya Islam dan Hindu dalam Masjid Menara Kudus," 2017.

[6] S. Salam, Menara Kudus: the minaret of Kudus. Centre for Islamic Studies and Research, 1989.
[7] S. Amin and G. F. Kurniawan, "Semarang cultural ecology in the grip of capitalism," in IOP Conference Series: Earth and Environmental Science, 2020, vol. 485, no. 1, p. 012048.

[8] S. Salam, Kudus selayang pandang. Gema Salam, 1995.

[9] N. Hosen, "Nahdlatul ulama and Collective ijtihad," New Zealand Journal of Asian Studies, vol. 6, pp. 5-26, 2004.

[10] A. Azra, Indonesia, Islam, and democracy: Dynamics in a global context. Equinox Publishing, 2006.

[11] T. Lindsey and H. Pausacker, Religion, law and intolerance in Indonesia. Routledge, 2016.

[12] N. Hosen, "Islam Nusantara: A Local Islam with Global Ambitions?," Indonesia at Melbourne, 2016.

[13] Syafwandi, Menara Mesjid Kudus: dalam tinjauan sejarah dan arsitektur. Bulan Bintang, 1985.

[14] J. W. Creswell and J. D. Creswell, Research design: Qualitative, quantitative, and mixed methods approaches. Sage publications, 2017.

[15] J. P. Spradley, The ethnographic interview. Waveland Press, 2016.

[16] L. Harvey, "Beyond member-checking: A dialogic approach to the research interview," International Journal of Research \& Method in Education, vol. 38, no. 1, pp. 23-38, 2015.

[17] R. C. Bogdan and S. K. Biklen, "Qualitative research in (validation) and qualitative (inquiry) studies," It is a method-appropriate education: An introduction to theory and methods, 2006.

[18] J. P. Spradley, Participant observation. Waveland Press, 2016.

[19] R. Suharso, W. Wasino, D. Setyowati, and C. Utomo, "Cultural Acculturation Values in The Minaret of Kudus to Foster Harmony Through Social Studies Education," presented at the Proceedings of the 5th International Conference on Science, Education and Technology, ISET 2019, 29th June 2019, Semarang, Central Java, Indonesia, Semarang, Indonesia, 2020, doi: 10.4108/eai.29-6-2019.2290440.

[20] T. Roesmanto, "Rupa Bentuk Menara Masjid Kudus, Bale Kulkul dan Candi," Jurnal Arsitektur, vol. 4, no. 1, 2013.

[21] D. Suryo, "Tradisi Santri dalam Historiografi Jawa, Pengaruh Islam di Jawa,” 2000.

[22] A. Yusof, A. H. Ali, M. Zin, and A. F. A. Hamid, "Islamic Nuance in Decorative-Ornament Architecture Art in Nusantara," International Journal of Nusantara Islam, vol. 2, no. 1, pp. 95104, 2014.

[23] S. Supatmo and S. Syafii, "Nilai Multukultural Ornamen Tradisional Masjid-Masjid Warisan Para Wali Di Pesisir Utara Jawa," Imajinasi: Jurnal Seni, vol. 13, no. 2, pp. 1-14, 2019. 
[24] H. J. de Graaf, T. G. T. Pigeaud, and J. Erkelens, Kerajaan Islam pertama di Jawa: tinjauan sejarah politik abad XV dan XVI. Pustaka Utama Grafiti, 2001.

[25] G. Eliraz, Islam in Indonesia: Modernism, radicalism, and the Middle East dimension. Sussex Academic Press Brighton, 2004.

[26] M. Kanzunnudin, F. Rokhman, S. A. Sayuti, and H. B. Mardikantoro, "Structure and Values of Story Pross of the People of Kudus Society," International Journal of Economic Research, pp. 175-182, 2017.

[27] I. W. Winaja, I. W. S. W. Prabawa, and P. R. Pertiwi, "Acculturation and Its Effects on the Religious and Ethnic Values of Bali's Catur Village Community," Journal of Social Studies Education Research, vol. 10, no. 3, pp. 249-275, 2019.

[28] B. Anderson and I. Communities, "Reflections on the Origin and Spread of Nationalism," London, New York, vol. 21993, 1991.

[29] M. I. Ahnaf, "Socio-Ethical Origin of Multiculturalism in Indonesia," Multiculturalism in Asia-Peace and Harmony, p. 126, 2018. 